\title{
Case Report \\ Serological Findings in a Child with Paroxysmal Cold Haemoglobinuria
}

\author{
Eduardo J. Salido, ${ }^{1}$ Valentín Cabañas, ${ }^{1}$ Mercedes Berenguer, ${ }^{1}$ María I. Macizo, ${ }^{2}$ \\ Faustino García-Candel, ${ }^{1}$ Raúl Pérez-López, ${ }^{1}$ and Jose M. Moraleda ${ }^{1}$ \\ ${ }^{1}$ Hematology Department, Hematopoietic Transplant and Cellular Therapy Unit, Virgen de la Arrixaca Clinical University Hospital, \\ IMIB-Arrixaca, University of Murcia, Carretera Madrid-Cartagena, s/n, El Palmar, 30120 Murcia, Spain \\ ${ }^{2}$ Laboratory Medicine Department, Virgen de la Arrixaca Clinical University Hospital, IMIB-Arrixaca, University of Murcia, \\ Carretera Madrid-Cartagena, s/n, El Palmar, 30120 Murcia, Spain
}

Correspondence should be addressed to Eduardo J. Salido; eduardosalido@hotmail.com

Received 25 June 2014; Accepted 20 September 2014; Published 9 October 2014

Academic Editor: Werner Rabitsch

Copyright (C) 2014 Eduardo J. Salido et al. This is an open access article distributed under the Creative Commons Attribution License, which permits unrestricted use, distribution, and reproduction in any medium, provided the original work is properly cited.

$\mathrm{PCH}$ is a rare autoimmune hemolytic anemia (AIHA) but is one of the most common causes of AIAH in children. For the diagnosis, it is important to perform the appropriate methods of serological investigation and show the typical biphasic reaction. This is a case report of a child who presented with features of haemolysis and was diagnosed with $\mathrm{PCH}$ of this way.

\section{Introduction}

Paroxysmal cold haemoglobinuria $(\mathrm{PCH})$ is a special type of hemolytic syndrome caused by cold agglutinins. The hemolysin involved was described in 1904 by DonathLandsteiner and is called Donath-Landsteiner (DL) antibody. Characteristically it is a biphasic hemolysin, and it is fixed to erythrocytes at cold temperatures and produces lysis at body temperature $\left(37^{\circ} \mathrm{C}\right)[1,2]$. Complement is required for lysis but plays little or no part in the fixation phase.

$\mathrm{PCH}$ is one of the most common causes of acute autoimmune haemolytic anaemia (AIHA) in young children, although it may affect patients of all ages. In children, $\mathrm{PCH}$ is commonly seen following a viral illness or after vaccination $[1,2]$.

We report a child who presented with features of haemolysis and was diagnosed as PCH. We emphasize the relevance of considering $\mathrm{PCH}$ in presence of autoimmune hemolytic anemia with intravascular haemolysis at $37^{\circ} \mathrm{C}$ and a direct antiglobulin (Coombs) test (DAT) positive for complement only and implement the appropriate methods of serological investigation.

\section{Case Report}

A 3-year-old previously healthy girl was admitted to the pediatric unit with a 5-day history of viral illness with asthenia, fever, cough, and rhinorrhea. Physical examination revealed jaundice and mild hepatomegaly.

The initial investigations revealed a hemoglobin level of $75 \mathrm{~g} / \mathrm{L}$, with normal white cell and platelet count. The blood smear showed a severe red cell agglutination with moderate number of spherocytes. The reticulocyte count was initially normal. Serum indirect bilirubin was $120 \mu \mathrm{mol} / \mathrm{L}$ with the indirect fraction of $111 \mu \mathrm{mol} / \mathrm{L}$ and $\mathrm{LDH}$ was $1380 \mathrm{U} / \mathrm{L}$. Analysis of the urine sample revealed the presence of coluria and weakly positive haemosiderin (Perls' reaction, Figure 1) indicating intravascular haemolysis, with absent bilirubin, and no red cells were seen under microscope. Renal function was normal. These results pointed towards an intravascular haemolysis.

We found a positive direct antiglobulin test (DAT) due to primarily complement sensitization $(+4)$ with C3d specificity and $\operatorname{Ig} G$ was negative. 


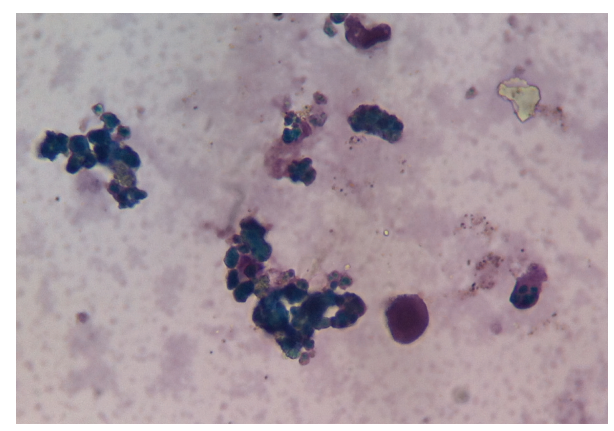

Figure 1: Hemosiderinuria. Perls' reaction weakly positive in the urine.

The cold agglutinin titre was not significant with adult cells, cord cells, and patient's cells. However, the DonathLandsteiner test was positive which was directed towards the diagnosis of $\mathrm{PCH}$.

In view of finding of an underlying cause, serological investigations were performed to discard infections (mycoplasma and EBV were negative) and serological investigations to detect Donath-Landsteiner hemolysin.

\section{Serological Investigations in PCH}

The diagnosis of PCH requires the demonstration of the typical serological reaction of Donath-Landsteiner hemolysin.

The DL antibody of PCH is an IgG antibody and has specificity for $\mathrm{P}$ antigens. It is far more lytic to normal cells in relation to its titre than the anti-I or anti-i antibodies. The lysis titre of a DL antibody may be the same as or greater than its agglutination titre. The maximal lysis develops in unacidified serum and this is inhibited by plasma [2].

3.1. Direct Donath-Landsteiner Test. We collected two samples of venous blood into tubes without anticoagulant, previously warmed at $37^{\circ} \mathrm{C}$. Later we incubated the first sample at $37^{\circ} \mathrm{C}$ for 1,5 hours. The second sample was incubated in a container filled with ice for 1 hour and afterwards was placed at $37^{\circ} \mathrm{C}$ for another 20 minutes. After the incubation time, both samples were centrifuged at $37^{\circ} \mathrm{C}$ and the supernatant serum was examined for lysis.

The test was positive for the presence of hemolysis in the sample that had been chilled (Figure 2, tube 2). Although the test was positive, we proceeded to confirm the presence of antibody by indirect Donath-Landsteiner test.

3.2. Indirect Donath-Landsteiner Test. We performed the indirect DL tests using serum obtained from the patient's blood that had been allowed to clot at $37^{\circ} \mathrm{C}$. We added 1 volume of $50 \%$ suspension of washed normal group $\mathrm{O}, \mathrm{P}-$ positive red cells to 9 volumes of the patient's unacidified serum in a tube. Then we chilled the suspension in crushed ice at $0^{\circ} \mathrm{C}$ for 1 hour. Afterwards we placed the tube at $37^{\circ} \mathrm{C}$ for 30 minutes, centrifuged it at $37^{\circ} \mathrm{C}$, and examined it for lysis (Figure 3, tube 1).

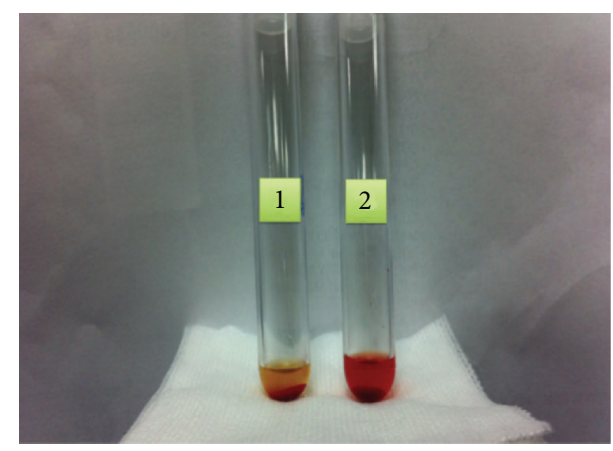

FIGURE 2: Direct Donath-Landsteiner positive test.

At the same time we used three control tubes:

(i) a duplicate tube of the test cell-serum suspension (tube 1) but conserved strictly at $37^{\circ} \mathrm{C}$ for the duration of the test (Figure 3, tube 2);

(ii) the adsorption of complement that can be prevented by adding a chelating agent, such as EDTA, to the serum. In this case there is no hemolysis, showing that reaction is complement dependent (Figure 3, tube 3);

(iii) a duplicate of the test cell-serum suspension, except that an equal volume of $\mathrm{ABO}$-compatible fresh normal serum was first added to the patient's serum as a source of complement. One volume of the 50\% cell suspension was added and the suspension chilled and subsequently warmed in the same way as the test suspension. This control excludes false negative results owing to the patient's serum being deficient in complement (Figure 3, tube 4);

(iv) a duplicate of the test cell-serum suspension, except that fresh normal serum was used in place of the patient's serum. This control also was chilled and subsequently warmed.

\section{Discussion}

PCH was first described as a distinct clinical entity in 1872 and the hemolytic antibody was described by Donath and Landsteiner. PCH is an intravascular hemolytic disease in which hemolysis is related to exposure to cold temperatures [1]. The DL hemolysin is an IgG cold antibody and has anti$\mathrm{P}$ specificity. However, in practice, almost all samples of red cells are suitable because the cells that will not react (Pk and $\mathrm{pp}$ ) are extremely rare $[2,3]$.

The incidence of $\mathrm{PCH}$ according to the data available is variable from 5 to $10 \%$ of autoimmune hemolytic anemia (AIHA) in children [1] and is one of the most common causes of acute AIHA in the young children [1]. In adults, $\mathrm{PCH}$ is rare, representing less than $1 \%$ of all AIHA [1]. A study found six cases of PCH in 100 children with AIHA [4].

The antibody is fixed on the erythrocytes at low temperature, and hemolysis later occurs at body temperature. Complement is necessary for hemolysis but not for fixation $[2,3]$. 


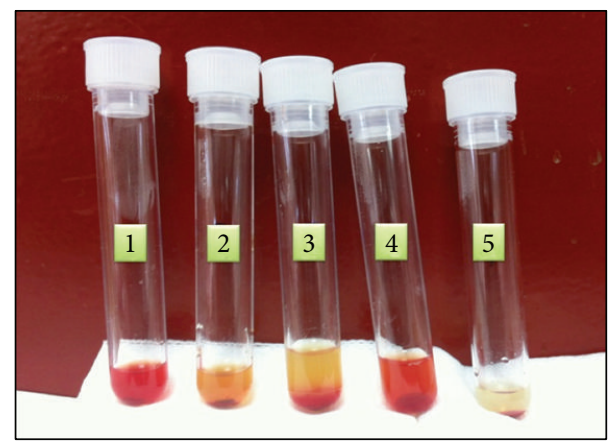

FIgURE 3: Indirect Donath-Landsteiner test. Tube 1: OP + red cells suspension + patient's serum. Double incubation at $0^{\circ} \mathrm{C}$ and $37^{\circ} \mathrm{C}$. Tube 2: duplicate of tube 1 but conserved strictly at $37^{\circ} \mathrm{C}$. Tube 3: duplicate of tube $1+$ compatible fresh normal EDTA-plasma and double incubation. Tube 4: duplicate of tube $1+$ compatible fresh normal serum and double incubation. Tube 5: OP + red cells suspension $+\mathrm{ABO}$ compatible fresh serum and double incubation.

The antibody was first observed as a cross-reacting antibody to an antigen on Treponema pallidum in the latter half of the 19th century. Today it is more common to find it in children with postviral illnesses [5], after immunization [6], and in patients with lymphoproliferative disorders and collagen vascular diseases [7].

Attacks of hemoglobinuria are precipitated by cold and hemolysis may occur immediately after exposure and is usually accompanied by fever, abdominal pain, and constitutional symptoms that resolves spontaneously within a few days to several weeks after onset $[1,5]$.

Regarding the laboratory findings, it is striking the relative reticulocytopenia in the presence of severe and rapidly progressive anaemia. Reticulocytopenia reflects an ineffective erythropoiesis either by destruction of precursor red cells by Donath-Landsteiner antibodies or by viral hemopoietic suppression $[1,4]$.

During the hemolytic crisis there may be methemoglobinemia and hemoglobinuria, the concentration of haptoglobin is reduced, and the LDH levels are greatly increased $[1,4]$.

Direct antiglobulin tests are usually positive during a paroxysm and negative at other times and it is complement and temperature dependent $[1,4]$.

Leukopenia occurs during or immediately after a paroxysm, followed by leukocytosis. In the blood smear it is common to observe spherocytosis, anisopoikilocytosis, fragmented red cells, basophilic stippling, polychromatophilia, autoagglutination, and nucleated erythrocytes $[1,4]$.

In our patient, urine haemosiderin positivity confirmed intravascular haemolysis and the C3d specificity supported an immune-mediated haemolysis mechanism.

To establish the correct diagnosis of $\mathrm{PCH}$, it is necessary to demonstrate the presence of the DL hemolysin using appropriate serological investigations as we have described, using both negative and positive controls. The DonathLandsteiner reaction is positive at all stages of the disease and may even persist for years, although during remission the hemolytic activity usually may be minimal [2].

In our patient, the cold agglutinin titre was also performed and it was not significant.

Determination of the specificity of the autoantibody is recommended, but it was not performed in our patient because almost all cases of $\mathrm{PCH}$ are associated with anti-P specificity, although other specificities associated with $\mathrm{PCH}$ have been rarely reported [1]. In practice it is impossible to determine the specificity of antibody due the great rarity of $\mathrm{P}$ negative cells [6].

Though acute attacks are normally severe, they characteristically resolve spontaneously within a few days or few weeks after the onset and rarely recur [1]. Our patient required only supportive care that included blood transfusion and warming.

The suspected diagnosis is important because corticosteroids are usually ineffective and unnecessary because of the transient nature of haemolysis [1]. Some adults have been treated with cyclophosphamide, rituximab was used successfully in rare refractory cases, and clearance of the antibody may be possible with plasma exchange $[7,8]$.

In conclusion, in patients with suspected $\mathrm{PCH}$ it is necessary to perform a correct diagnosis by serological demonstration of DL hemolysin because management may be different from other hemolytic anemia.

\section{Conflict of Interests}

The authors declare that there is no conflict of interests regarding the publication of this paper.

\section{References}

[1] L. D. Petz, "Cold antibody autoimmune hemolytic anemias," Blood Reviews, vol. 22, no. 1, pp. 1-15, 2008.

[2] B. J. Bain and N. Win, "Acquired haemolytic anaemias," in Dacie and Lewis Practical Haematology, M. Lewis, B. J. Bain, and I. Bates, Eds., pp. 273-300, Elsevier, 11th edition, 2011.

[3] S. M. Worlledge and C. Rousso, "Studies on the serology of paroxysmal cold hemoglobinuria $(\mathrm{PCH})$ with special reference to a relationship with the P blood group system," Vox Sanguinis, vol. 10, pp. 293-298, 1965.

[4] S. Vaglio, M. C. Arista, M. P. Perrone et al., "Autoimmune hemolytic anemia in childhood: serologic features in 100 cases," Transfusion, vol. 47, no. 1, pp. 50-54, 2007.

[5] M. A. Gertz, "Cold hemolytic syndrome," Hematology, pp. 1923, 2006.

[6] C. Bunch, F. C. Schwartz, and G. W. Bird, "Paroxysmal cold haemoglobinuria following measles immunization," Archives of Disease in Childhood, vol. 47, no. 252, pp. 299-300, 1972.

[7] M. A. Gertz, "Management of cold haemolytic syndrome," British Journal of Haematology, vol. 138, no. 4, pp. 422-429, 2007.

[8] A. Koppel, S. Lim, M. Osby, G. Garratty, and D. Goldfinger, "Rituximab as successful therapy in a patient with refractory paroxysmal cold hemoglobinuria," Transfusion, vol. 47, no. 10, pp. 1902-1904, 2007. 


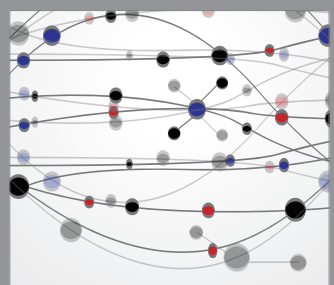

The Scientific World Journal
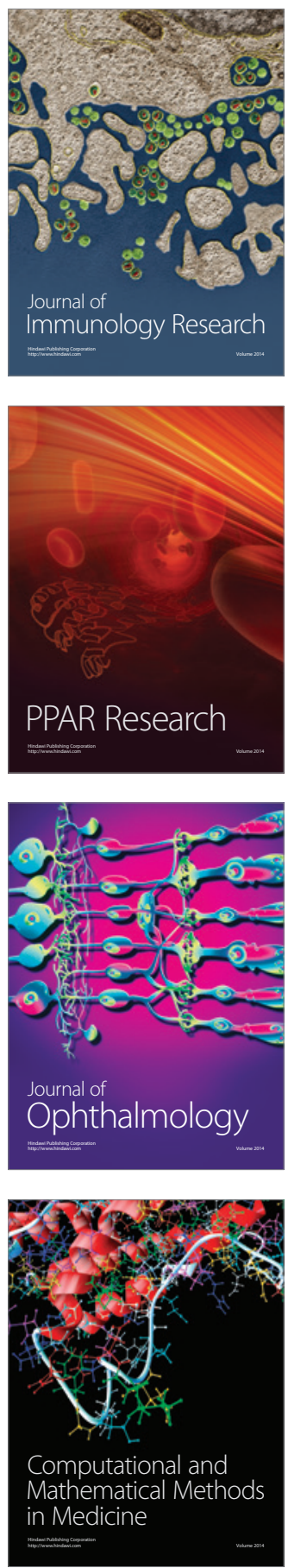

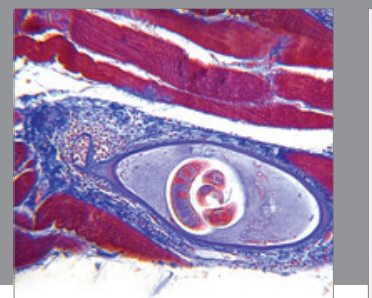

Gastroenterology

Research and Practice
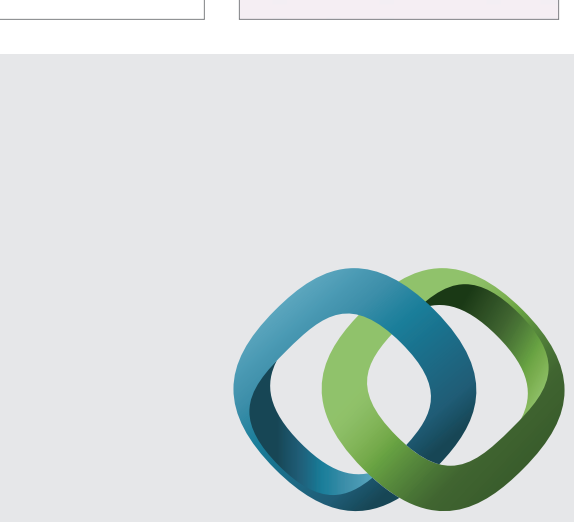

\section{Hindawi}

Submit your manuscripts at

http://www.hindawi.com
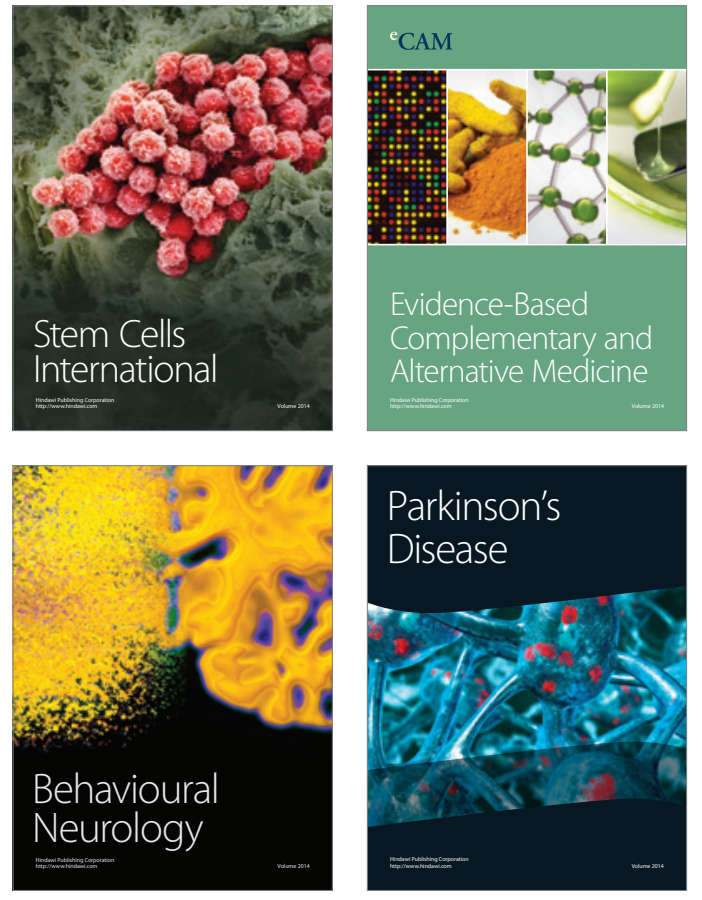
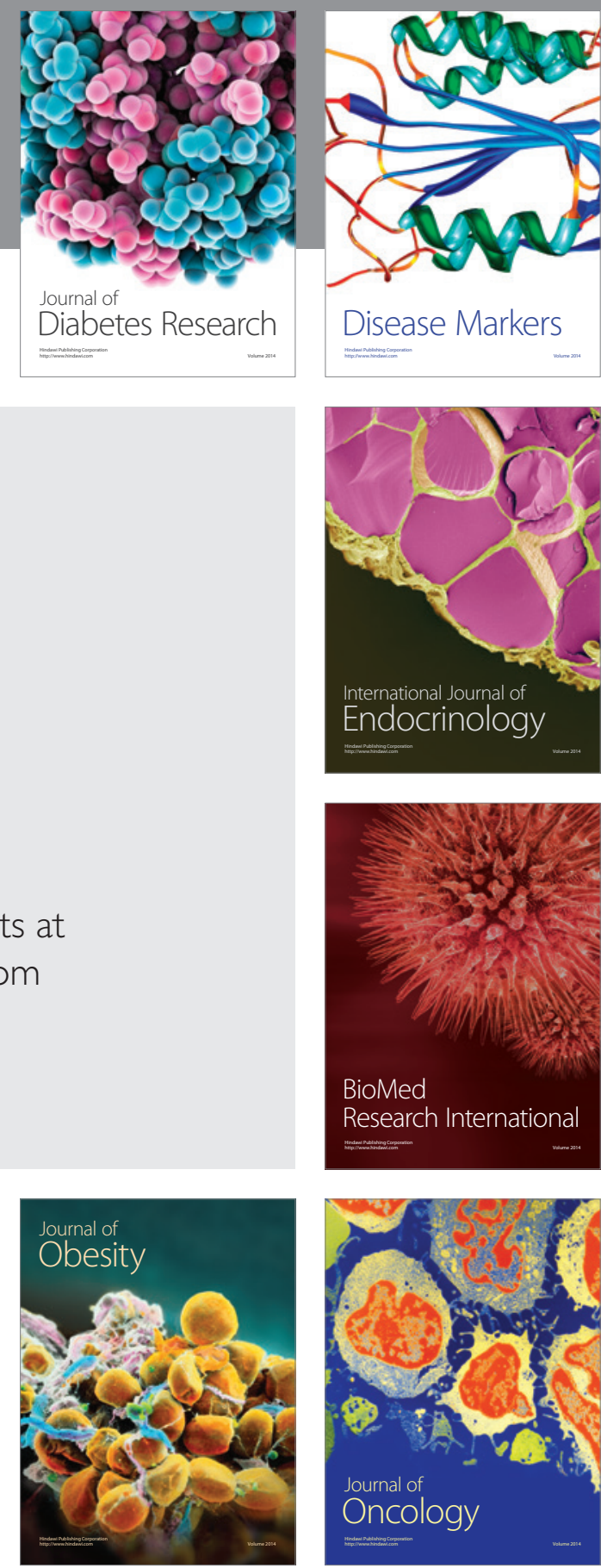

Disease Markers
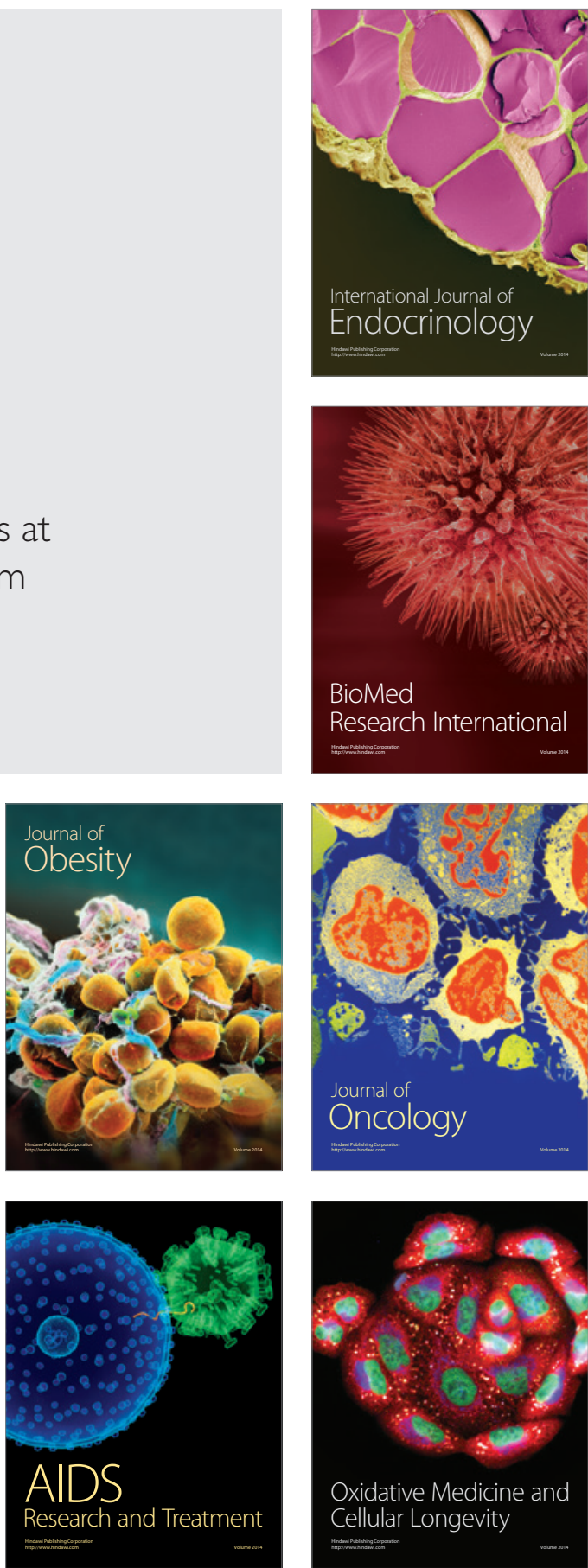